\title{
反回神経の変性および再生過程の形態学的観察
}

南 仁成, 進 武 幹, 渡辺 宏
前山忠嗣, 森川 郁 郎, 梅 崎 俊 郎

\section{Morphological Observation of the Degeneration and Regeneration Process of the Recurrent Laryngeal Nerve}

\author{
Insung Nahm, M.D., Takemoto Shin, M.D., Hiroshi Watanabe, M.D., \\ Tadatsugu Maeyama, M.D., Ikuro Morikawa, M.D., \\ and Toshiro Umezaki, M.D. \\ Department of Otolaryngology, Saga Medical School, Saga
}

Paradoxical movements and abnormal electromyographical findings of laryngeal muscles following recurrent laryngeal nerve (RLN) injury may reflect quantitative and qualitative defects in the reinnervation process. The purpose of this study was to clarify morphological changes caused by reinnervation after freezing nerve injury.

Hartley guinea pigs weighing $300-400 \mathrm{~g}$ were anesthetized with pentobarbital. The left RLN was injured by freezing $\left(-80^{\circ} \mathrm{C}\right)$ at the level of the 10th tracheal ring. At intervals ranging from 2 weeks to 6 months, animals were reanesthetized and horseradish peroxidase (HRP) was injected into the left posterior cricoarytenoid (PCA) muscle. Animals were fixed by perfusion 48 hours after the HRP injection, and examined for the presence of retrogradely labeled perikarya in the medulla oblongata. Projections to the individual laryngeal muscles, as well as entire RLN, were also recruited as normal controls. On the other hand, we researched the histological degeneration and regeneration process of RLN following freezing injury.

Injection of HRP in normal PCA muscle labeled a well defined area within the ipsilateral nucleus ambiguus. From two to six months after the freezing injury, the number of labeled neurons increased gradually from 11 to 73 . In addition, we were able to observe that the area occupied by neurons which project to the PCA muscle expanded, but was confined within the region of perikarya projecting to the normal RLN. Through the light and electron microscopic observations, most axons degenerated within 3 days and showed regenerative sprouting by 7 days after the injury. One of the most striking feature of nerve regeneration after freezing injury is rapid sprouting and maturing of regenerating axons compared to the other injuries. Target specific reinnervation was not accomplished even after freezing injury which produced minimum disorganization to the structure of RLN fibers.

Key words : misdirected regeneration, recurrent laryngeal nerve, freezing nerve injury 


\section{はじめに}

末梢神経は損傷されるとその部より末梢側は ワーラー変性に陥るが，その後再生が起こって くる。反回神経のように同一神経が拮抗筋を支 配している場合には，再支配が正確に行われな いと神経は再生しても機能障害が生じること は，実験的にも，また臨床的にもよく知られて いる。われわれは，軸索とシュワン細胞などの 細胞成分のみを死滅させる目的で，モルモット の反回神経に凍結損傷を加え, その変性と再生 の過程を最長 6 力月まで観察した。損傷部より 末梢の変化を光顕および電顕を用いて観察し, また HRP 標識法を用いて内喉頭筋を支配する 運動神経細胞の再配列を観察した。

\section{研究材料および方法}

実験には計22匹のモルモットを用い，正常対 照群と凍結損傷群の二群に分けた。正常対照群 としては 9 匹（体重600～900 g）を用いた。 Sodium pentobarbital (ネンブタール, $30 \mathrm{mg}$ / $\mathrm{kg}$ B.W.) で腹腔内麻酔の後, 前頸部皮膚を正 中切開して喉頭および反回神経を露出した。3 匹の左甲状披裂筋（内筋）抢よび側輪状披裂筋 (側筋) と 3 匹の後輪状披裂筋（後筋）に生理食 塩水に溶かした $30 \%$ HRP (Sigma, type VI) $2 \sim 3 \mu 1$ を微小ガラス管を用い注入した。残り の 3 匹については左反回神経を第10気管輪で切 断し，その中枢側を HRP 溶液が入っているガ ラスチューブに入れて，アロンアルファ ${ }^{\circledR} て ゙$ 固 定した。

HRP 注入 48 時間後, 再びネンブタールによ る深麻酔下で開胸し，心尖部より上行大動脈に カニューレを挿入した。カニューレを通して生 理食塩水 $200 \mathrm{ml}$ を灌流し, ついで1.25\% glutaraldehyde $-1.5 \%$ paraformaldehyde $-0.1 \mathrm{M}$ リ ン酸緩衝液 $(\mathrm{pH} 7.4) 500 \mathrm{ml}$ にて灌流固定を行 つた。

固定後，直ちに延髄，喉頭および左反回神経 を摘出した。摘出した延髄は $30 \%$ sucrose を含 む $4{ }^{\circ} \mathrm{C}$ リン酸緩衝液 $(\mathrm{pH} 7.4)$ に2 時間浸漬 後, 厚さ50 $\mu \mathrm{m}$ の連続横断凍結切片を作製し た。HRP 陽性細胞の検出には, tetramethyl benzidine (TMB)を用いた ${ }^{1,2)}$ 。中性赤による比
較染色後, 光学顕微鏡により疑核内 HRP 陽性 細胞を観察し, その数と分布を二次元的に構成 した。

凍結損傷群は13匹（体重300～400）を用い， 左反回神経に輪状軟骨の下縁から $12 \mathrm{~mm}$ の部 で涷結損傷を加えた。凍結にはー $80^{\circ} \mathrm{C} の$ dry ice で処理したピンセットを用い, 凍結と溶解 (室 温）を 10 秒ずつ 3 回繰り返した。 2 週間から 6 力月後, 同側の後筋に HRP を注入し, 正常群と 同様の方法で再生運動ニューロンの分布を調 べ，正常対照群と比較した。

変性および再生過程の組織学的観察のために は, 灌流固定後直ちに損傷した所から $3 \sim 6$ $\mathrm{mm}$ 末梢側の神経を $2 \mathrm{~mm}$ の長さで採集した。 同一の固定液に $4{ }^{\circ} \mathrm{C} て ゙ 12$ 時間浸漬して，2\%四 酸化オスミウムによる 2 時間の後固定の後, 型 通り脱水を行い, スパー樹脂包埋を行った。試 料はミクロトームで超薄切片を作製し，1％酢 酸ウラニルおよびクエン酸鉛にて二重電子染色 してJEOL-100CX 型電子顕微鏡で観察した。

\section{結果}

\section{HRP 標識細胞の分布}

正常対照群（表 1，図 1)：反回神経全体の HRP 陽性細胞は obex の尾側約 $2.0 \mathrm{~mm}$ から 吻側約 $2.0 \mathrm{~mm}$ の高さまで存在し, その数が二 つのピークを示すのが認められた。そのうち内 筋および側筋の運動ニューロンは obex の尾側 約 $2.0 \mathrm{~mm}$ から吻側約 $0.5 \mathrm{~mm}$ まで存在し, 後 筋のそれはやや吻側にかたより,obex の尾側約 $1.0 \mathrm{~mm}$ より吻側 $0.5 \mathrm{~mm}$ まで認められた。

二次元的に観察すると, 後筋注入例の標識細 胞は反回神経全体の運動ニューロンの分布領域 の中で吻側 $1 / 3 て ゙ は$ 全領域に広がって見られた が，それより尾側では腹側部の方に集中してい た。一片，内筋および側筋注入例の標識細胞は 全体領域に存在し，広い範囲にわたって散在し ているように認められた。このように反回神経 支配の後筋と内筋および側筋の運動ニューロン 分布領域にはわずかながら差が認められた。

凍結損傷群(表 2 , 図 2)：延髄内の後筋運動 ニューロンの標識細胞は凍結損傷 2 力月後に初 めて認められ，その数が徐々に増加し，6力月 後には正常対照群と殆ど差は認められなかっ 
表 1 Summary of results following the injection of HRP into intrinsic laryngeal muscles and recurrent laryngeal nerve of the guinea pig (正常対照群)

\begin{tabular}{cccc}
\hline \multirow{2}{*}{$\begin{array}{c}\text { Injection } \\
\text { site }\end{array}$} & \multirow{2}{*}{$\begin{array}{c}\text { Animal } \\
\text { number }\end{array}$} & \multicolumn{2}{c}{ Labeled neurons } \\
\cline { 3 - 4 } & & NA & RFN \\
\hline TA·LCA & 3 & $67^{*}$ & $(48-83) * *$ \\
PCA & 3 & 71 & $(58-88)$ \\
RLN & 3 & $118(96-133)$ & $55(47-63)$ \\
\hline
\end{tabular}

NA, nucleus ambiguus; RFN, retrofacial nucleus : TA-LCA, thyroarytenoid-lateral cricoarytenoid muscles ; PCA, posterior cricoarytenoid muscle ; RLN, recurrent laryngeal nerve. *Mean, ${ }^{* *}$ range.

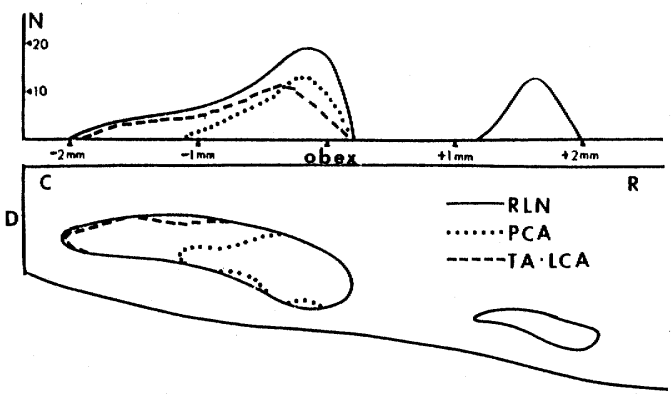

図 1 正常対照群における延髄内 HRP 標識細胞の 領域

PCA, posterior cricoarytenoid muscle ; TA - LCA, thyroarytenoid-lateral cricoarytenoid muscles; $\mathrm{RLN}$, recurrent laryngeal nerve; $\mathrm{C}$, caudal, $\mathrm{R}$, rostral ; D, radial distance from the margin of the 4 th ventricle or central canal ; $N$, number of cells.

た。6カ月後の標識された後筋運動ニューロン の分布領域を正常対照群と比較してみると, や や尾側，すなわち内筋および側筋支配ニューロ ンの領域にまで広がっているのが認められた。

これを二次元的にみてみると, 後筋を再支配 した再生神経の一部（少なくとも20\%）が正常 後筋運動ニューロン領域の外に散在して広がっ ているのが観察された。

\section{2. 末梢神経の組織学的変化（図 3 )}

凍結損傷 3 日後に反回神経の損傷部より末梢 側では軸索がほぼ完全に消失し, 髄鞘の破壊が
表 2 Summary of results after injection of HRP into posterior cricoarytenoid muscle following various intervals after freezing injury of recurrent laryngeal nerve（凍結損 傷群)

\begin{tabular}{lcc}
\hline $\begin{array}{l}\text { Time } \\
\text { interval }\end{array}$ & $\begin{array}{c}\text { Animal } \\
\text { number }\end{array}$ & $\begin{array}{c}\text { Labeled cells } \\
\text { in nucleus ambiguus }\end{array}$ \\
\hline 2 weeks & 2 & \multicolumn{2}{c}{0} \\
1 month & 2 & 0 \\
2 months & 3 & $19^{*}(0-57) * *$ \\
3 months & 2 & $11 \quad(0-22)$ \\
4 months & 2 & $47 \quad(46-47)$ \\
6 months & 2 & $73 \quad(52-94)$ \\
\hline
\end{tabular}

${ }^{*}$ Mean, ${ }^{* *}$ range.

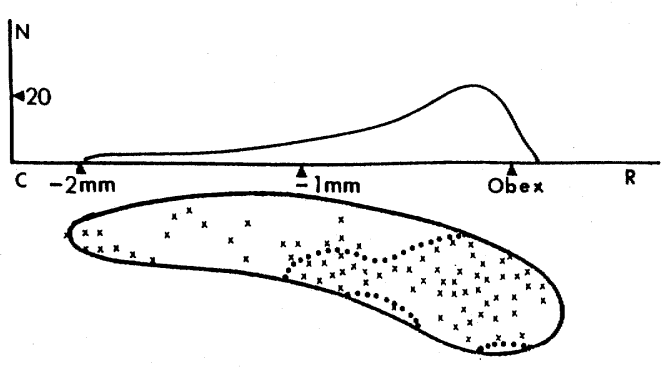

図 2 反回神経凍結損傷 6 力月後, 後筋を再支配し た運動ニューロンの分布領域 (* location of labeled cells)

著明であった。1 週間後には変性は完了し，髄 鞘を貧食している大型の食細胞が多数認められ た。シュワン細胞は増殖し，末熟な小型の axon sprout を数多く含む axon-schwann cell unit を形成していた。この時期の軸索あるいはシュ ワン細胞核の一定の面積あたりの数を数える と, 正常の 4 倍以上に増加していた。10日後か らは髄鞘が形成されながら axon-schwann cell unit はそれぞれの成熟した神経線維に再構築 されていくのが観察された。再生線維はその後, 徐々に正常の形に近づき， 3 力月目には神経線 維の数と大きさはほぼ正常になったが，まだ形 態は不規則な形を呈していた。 
日気食会報，40（6）, 1989

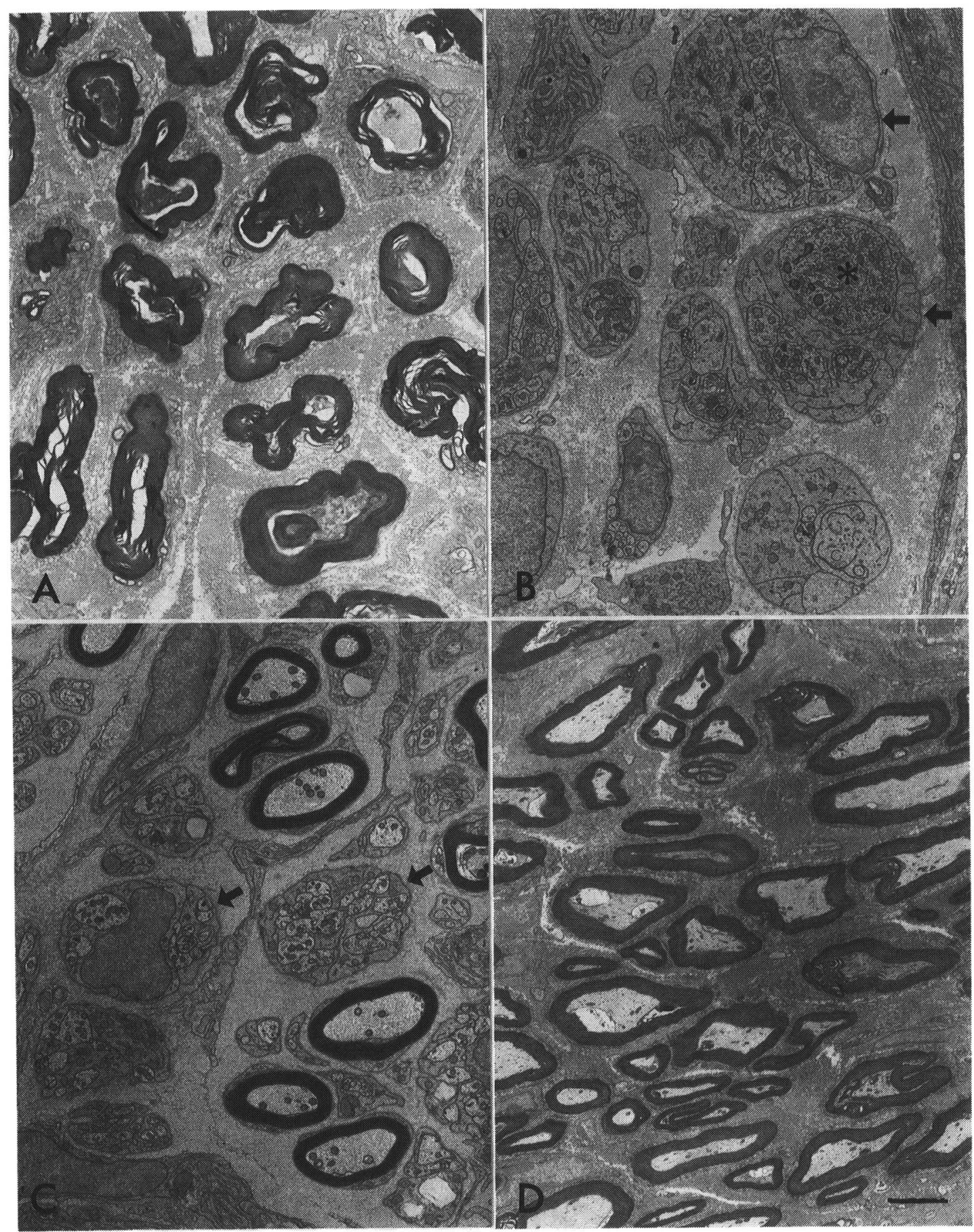

図 3 反回神経凍結損傷後, 末梢側の変性および再生の過程 A， 3 日後； B , 7 日後；C，14日後；D，3 力月後。 Axon-Schwann cell unit（arrow）と Growth cone（star）が見られる。Bar=2 $\mu \mathrm{m}$ 


\section{考察}

神経再生における misdirected regeneration を最初に報告したのは Lipschits ${ }^{3}$ であり，これ を反回神経において確認したのは Siribodhi ら"仿初めてである。彼らはイヌの実験的反回 神経麻痺の声帯運動および声帯固定位置につい ての研究の中で反回神経の misdirected regeneration 筋電図を用いて検討していた。 さらに富田ら ${ }^{5}$ はヒト反回神経麻痺患者でこの misdirected regeneration 筋電図学的に証明 した。

広戸ら ${ }^{6}$ はその機序として反回神経は損傷さ れると，他の末梢神経と同じように，中枢端か ら再生してくる個々の分枝と筋肉との結合は損 傷前の結合とは無関係に行われるので，単一軸 索より再生した神経分枝のすべてが損傷前には 支配していなかった筋肉を新しく支配する場合 もあるし，単一軸索よりの数分枝がおのおの 別々に数個の筋を支配する場合もあり，上喉頭 神経外枝のように，神経と筋肉との対応が 1 対 1 の場合，あるいはほかの末梢神経のようにい くつかの協力筋を支配する場合は misdirected regenerationがおこっても機能障害が生じな いが，特に反回神経のように，同一神経が拮抗 筋を支配している場合には機能障害を生じると 説明した。

さて，末梢神経の再生軸索は損傷後シュワン 細胞の表面に沿って伸びることが明らかとなっ ている7)。シュワン細胞は再生軸索の通路であ ると同時に，再生軸索を誘引したり，その成長 を促す栄養物質を出すものと考えられ, 神経再 生に不可欠のものとされてきた7)。さらに，井 手8)はまわりの組織をできるだけ正常のまま残 して，シュワン細胞など細胞成分だけを死滅さ せる目的で, 凍結処理した神経を元の場所に植 えて経時的に観察した結果，シュワン細胞なし でも基底膜さえ温存されていれば再生軸索が基 底膜のトンネル内を伸びていくことを証明し た。

以上のことよりわれわれは, 細胞成分のみを 障害して基底膜はそのまま保存する凍結損傷を この実験に用いた。凍結損傷における misdirected regenerationを証明するために, 主に形
態学的変化に主眼をおいて，末梢側の再生過程 の観察と同時に逆行性標識法を用いて延䯣内の 後筋運動ニューロンの再配列を観察した。

逆行性標識法による動物の内喉頭筋支配運動 ニューロンの延髄内分布の同定は Hinrichsen and $\operatorname{Ryan}^{9)}$ (ラット), Yoshida et al. ${ }^{10)}$ (ネコ), Davis and Nail ${ }^{11)}$ (ネコ，ウサギ), Hisa et al. ${ }^{12)}$ (イヌ), Okubo et al. ${ }^{13)}$ (ウサギ）などによって 詳しく調べられている。反回神経全体の運動二 ユーロン領域と内転筋である内筋および側筋領 域，外転筋である後筋領域を比較して見ると基 本的に他の動物種と一致していた。しかし，反 回神経全体の運動ニューロン分布領域で吻側に もう一つの小型の標識細胞群が retrofacial nucleus 内に存在した。これらの運動ニューロン は反回神経内の細い神経線維を送り, 気管や食 道の筋肉を支配している ${ }^{14)}$ 。

後筋運動ニューロンの延髄内再配列を経時的 に観察してみると, 凍結損傷 6 力月後の再生後 筋運動ニューロンは, 反回神経全体の領域に幅 広く散在していて，定量的に観察するとその 20 \%程度が本来の後筋運動ニューロン領域以外, すなわち側筋および内筋領域で認められた。こ の所見は内転筋支配神経細胞による外転筋への misdirected regeneration が生じたことを意味 している。

次に組織学的な末梢側の変化では，まず凍結 損傷でもその末梢側はすべてワーラー変性が起 こるのが認められた。神経周膜や神経上膜の変 化は軽度で結合組織は少量増える程度であっ た。変性した軸索や髄鞘はまわりのシュワン細 胞によって貧食され，外からのマクロファジの 遊走は少なかった。増殖したシュワン細胞や axon sprout の増加率は機械的損傷，すなわち crushing injury あるいは切断縫合に比べたら 少ないが，再生の形態的変化の過程は同様であ った ${ }^{15)}$ 。神経再生の特徵である axon-schwann cell unit や growth cone の形成なども凍結以 外の損傷後の再生過程と同様であった。

今回の実験結果より，比較的軽度の損傷であ り，基底膜を保つ凍結損傷においても，機械的 損傷と同様に, misdirected regeneration が起 こりうることが証明された。このような misdirected regenerationの機序にはまだまだ不明な 
点が多く，今後さらに検討する必要がある。

\section{ま と め}

軸索とシュワン細胞などの細胞成分のみを死 滅させる目的で凍結損傷をモルモットの反回神 経に加え, その変性と再生の過程を最長 6 力月 まで観察した。後筋への HRP 注入の結果では, 2 力月目から標識細胞が認められ 6 力月目には 正常対照群の後筋支配運動神経の数とほぼ同じ 数にまで回復した。しかしながら，再生運動神 経細胞体の分布の分析結果より，本来の後筋支 配領域以外の細胞体からの投射も起こっている ことが確認された。損傷部より末梢側では損傷 後, 軸索が完全に消失し髄梢の破壊がみられた が， 1 週後には細い再生軸索が多数観察された。 再生神経の形態は 3 力月後でもなお不規則であ った。

稿を終えるにあたり，ご指導を賜った千葉大学医 学部解剖学教室千葉胤道教授に感謝致します。

本研究は昭和63年度科学研究費補助金 (研究課題 番号：62570781）交付を受けた。

本論文の要旨は第 40 回日本気管食道科学会学術講 演会 (昭和63年11月 12 日，広島，広島厚生年金会館) において発表した。

\section{文献}

1) Mesulam, M.M. : TMB for HRP neurohistochemistry : A non-carcinogenic blue reaction product with superior sensitivity for visualizing neural afferents and efferents. J. Histochem. Cytochem., 26:106-117, 1978.

2) Mesulam, M.M., et al.: Additional factors influencing sensitivity in the TMB method for HRP neurohistochemistry. J. Histochem. Cytochem., $28: 1255-1259,1980$.

3 ) Lipschitz, R.: Beiträge zur Lehre von der Facialislähmung nebst Bemerkungen zur
Frage der Regeneration. Mschr. Psych. Neurol., 20:84, 1959.

4) Siribodhi, C., et al.: Electromyographic studies of laryngeal paralysis and regeneration of laryngeal motor nerves in dogs. Laryngoscope, $73: 148-164,1963$.

5 ) 富田英寿：反回神経麻疾の筋電図学的研究. 日 耳鼻, 70：964-985, 1967.

6 ) 広戸幾一郎：発声機構の面よりみた喉頭の病態 生理.耳鼻臨床，59：229-291，1966.

7 ) Cajar, S.R. : Degeneration and Regeneration of the Nervous System, Hafner, London, 1968 (Facsimile of the 1928 Edition), p.238.

8 ) 井手千束：未梢神経の再生. 電子顕微鏡， 21 : 167-173, 1987.

9) Hinrichsen, C.F.L., and Ryan, A.T. : Localization of laryngeal motoneurons in the rat: Morphological evidence of dual innervation? Exp. Neurol., $74: 341-355,1981$.

10) Yoshida, Y., et al.: Arrangement of motoneurons innervating the intrinsic laryngeal muscles of cats as demonstrated by horseradish peroxidase. Acta Otolaryngol., 94:329-334, 1982.

11) Davis, P.J., and Nail, B.S. : On the location and size of laryngeal motoneurons in the cat and rabbit. J. Comp. Neurol., 230:13-32, 1984.

12) Hisa, Y., et al.: Neucleus ambiguus motoneurons innervating the canine intrinsic laryngeal muscles by the fluorescent labeling technique. Exp. Neurol., 84: 441-449, 1984.

13) Okubo, J., et al. : Localization of rabbit laryngeal motoneurons in the nucleus ambiguus. Exp. Neurol., 96 : 528-539, 1987.

14) Gacek, R.R., and Lyon, M.J.: Fiber components of the recurrent laryngeal nerve in the cat. Ann. Otol. Rhinol. Laryngol., 85 : 460-471, 1976.

15) Bray, G.M., and Aguayo, A.J. : Regeneration of peripheral unmyelinated nerves. Fate of the axonal sprouts which develope after injury. J. Anat., $117:$ 517-529, 1974. 